\title{
Editorial
}

\section{More data mean better tools for South Africa}

http://dx.doi.org/10.17159/2413-3108/2017/i59a2069

In February this year, Statistics South Africa (Stats SA) released the findings of the 2015/16 Victims of Crime Survey, and announced that it would release the 2016/17 results in November. Victim surveys, though not without fault, capture valuable data relating to crime, justice and safety that are not typically collected by criminal justice agencies. Much of this data's value lies in their ability to identify victimisation trends that may or may not appear in police data, and to gauge perceptions and experiences of criminal justice institutions.

A few weeks after the Victim Survey's release, the South African Police Service (SAPS) published crime statistics for the last nine months of 2016. Ordinarily, South Africans have had to wait until September to access crime data for October to December of the previous year. The March 2017 release is part of the SAPS's commitment, made last year, to release quarterly rather than only annual crime data. This is a significant development for all invested in crime, justice and safety in the country.

The most recent Victim Survey covers the period April 2015 to March 2016, so is best read in conjunction with the SAPS data for that year. Both sets of data reveal some notable trends.

First, more households (42\%) believed violent crime in their area had increased in the three years preceding the survey than those who believed it had stayed the same (30\%) or declined (28\%). This marks a significant increase from 2011 when $31 \%$ believed it was increasing, but a decrease from $44 \%$ in $2014 / 15$. The belief that violent crime is on the rise is partially supported by SAPS murder data - our best proxy for violent crime - which saw 5\% more murders reported in 2015/16 than in the previous year. The Western Cape was the only province in which more than $50 \%$ of Victim Survey respondents believed violent crime was increasing. This too correlates with SAPS murder data, which show that Cape Town is South Africa's most violent city. Though not comparable to the Victim Survey, the March 2017 SAPS data suggest a tiny (0.01\%) decline in murder, nationally.

The Victim Survey captured similar perceptions regarding property crime, with more respondents believing it had increased (46\%) than decreased (26\%) or stayed the same (28\%). Again, significantly more respondents questioned in 2015/16 believed property crime had increased than did those surveyed in 2011/12 (34\%), and again this marked a minor decline in the same views from 2014/15 (47\%). Again, the Western Cape is the only province in which more than half of respondents (58\%) believed property crime was getting worse. However, SAPS data on property-related crime suggest that reports decreased in 2015/16.

The three crime types that Victim Survey respondents thought to be the most common, and that they also feared most, were burglary (59\%), street robbery (39\%) and home robbery (39\%). The most 
common types of crime experienced by respondents were home burglary (5\%), followed by home robbery (1\%), theft from car (1\%) and theft of livestock (1\%). Street robbery did not feature in the 10 most commonly experienced crimes. All the most commonly experienced crime types, except crop theft, saw slight year-on-year declines.

In contrast to the Victim Survey data, the SAPS data for both September 2016 and March 2017 show notable increases in aggravated robbery, including carjacking and robbery at residential and non-residential premises. Of those Victim Survey respondents who reported that they experienced robberies in 2015/16, 66\% of home robbery victims and $44 \%$ of other robbery victims had reported their experiences to police. This compares to just 60\% who had reported home robberies and 33\% who had reported other robberies to police in 2011. As such, the uptick in robberies found in the SAPS data may indicate changes in reporting, rather than in offending rates.

Nevertheless, it is concerning that the SAPS data suggests an increase in robberies, considering that robberies are some of the few categories of crime that police should be able to reduce. This is because common robbery is likely to occur in policeable geographic areas (hotspots), while other types of robbery are most likely carried out by experienced repeat offenders or organised syndicates, entrenched in networks that police should be able to infiltrate and disrupt.

Notably, though perhaps unsurprisingly, only $2 \%$ of Victim Survey respondents believed that 'white collar crime' may be the most common type in South Africa. This reveals an important bias in the way crime is conceived here, as elsewhere. It is very likely, as Robert Reiner points out in a new book, Crime: the mystery of the common-sense concept, that 'victimless' white collar crime, including corporate, financial and state crime, 'is likely to massively outstrip in extent and seriousness either victim-survey or police-recorded statistics'. ${ }^{1}$

With the disbandment in 2008 of the Directorate for Special Operations (the Scorpions), the elite investigative arm of the National Prosecuting Authority (NPA), the ability to tackle corporate and state crime in South Africa was significantly weakened. The DSO was replaced by the Directorate for Priority Crime Investigations (the Hawks), which, many have suggested, has been 'captured' by those close to President Jacob Zuma, effectively shielding him and dirty business entities (e.g. the Gupta business empire) from investigation and prosecution.

Despite its potential for massive harm, it can be hard to view corporate and state crime as being as threatening as an angry adolescent hanging around a bus terminus late at night. The 2015/16 Victim Survey reveals that since 2011 there has been a notable decrease in the number of people who feel safe walking in their area of residence during the day (from 89\% to 84\%) and at night (from 37\% to $31 \%)$. Asked whether they were prevented from engaging in daily activities because of crime, a third of 2015/16 respondents reported being unable to use public spaces, and 23\% reported being unable to let their children play outside.

The first months of 2017 have seen flare-ups of anti-foreigner/xenophobia-related violence and sentiment, particularly in Gauteng where foreign nationals have been blamed for stealing jobs and generating crime. And yet, as in previous years, around two-thirds of Victim Survey respondents believed that 'people from this area' were the most likely perpetrators of crime, compared to roughly $6 \%$ who believed 'people from outside South Africa' were to blame. Most believe people commit crime for 'drugs-related need', followed by 'genuine need'. 
In asking where government should spend money to reduce crime, the 2015/16 Victim Survey introduced a new category to its usual options. Previously, two-thirds of respondents consistently chose 'social/economic development'. In 2015/16 this was split into two categories, 'social development' and 'economic development', with $61 \%$ choosing the latter and only $7 \%$ the former.

There is plenty more of interest and value in both the Victim Survey and the SAPS quarterly crime data, and I would encourage readers of South African Crime Quarterly (SACQ) to look them up. There is, however, one more point worth mentioning on the subject. People living in in South Africa are not necessarily more likely to become victims of crime than are residents of, for example, West European countries. We know this because we can compare Victim Survey data collected here to data collected in Europe and elsewhere, using comparable methodologies. What sets South Africa apart is not the prevalence of crime, but its violence, and its impact on lives already characterised by fragility and precariousness. ${ }^{2}$

\section{What's in this issue?}

The first issue of 2017 is one of variety in form and subject.

We begin with Lisa Vetten's thorough review of the adherence to, and implementation of, legislative duties placed on police by the 1998 Domestic Violence Act. Based on annual reports and parliamentary minutes, the article demonstrates what is often so very true of policing - that impressive oversight architecture and legislation does not necessarily produce the kind of police practice that is envisaged.

This is followed by an article by Robert Nanima, evaluating the discretion of the Minister of Justice and Constitutional Affairs to refuse parole to those serving life sentences under Section 78(2) of the Correctional Services Amendment Act. It examines the drafting of the relevant section of the Act, evaluates the extent of ministerial power, and reviews its application in the 2014 case Barnard $v$ Minister of Justice. Using it as a case study, Nanima recommends that the minister's powers with regard to parole be revisited.

The last of our three research articles is an exceptionally creative piece by Simone Haysom and Mark Shaw. In it they ask why organised crime figures choose to live and work in particular areas, exploring the question in relation to gang boss Radovan Krejcir and the Johannesburg suburb of Bedfordview. The analysis identifies several push and pull factors that make Bedfordview desirable to crime bosses.

A case note by Franaaz Khan explores a 2015 Constitutional Court decision in the case De Vos NO $\checkmark$ Minister of Justice and Constitutional Development. The decision related to the constitutionality of Section 77 of the Criminal Procedures Act. Section 77 deals with the treatment of an accused person who, due to mental illness, is unfit to stand trial, but is still required by law to be detained. Perhaps unsurprisingly, the court found that the section breached the accused's right to freedom. Khan tells us how and why.

A review essay by Ardil Jabar and Richard Matzopoulos builds on related violence prevention work published in SACQ in recent years. This approaches violence not as a criminal justice matter but rather a public health and 'whole of society' issue. Through a review of related concepts and literature, the authors describe the concept of a violence observatory, and suggest that South Africa would benefit from the establishment of such an entity. 
We end this issue with an On the Record interview with Deputy National Commissioner and head of the SAPS Management Intervention division, Lt Gen. Gary Kruser. In the interview, conducted by Johan Burger, Kruser describes some of the innovative and important changes taking place within the SAPS, including insight into its Back-to-Basics programme.

Please enjoy.

\section{Andrew Faull}

(Editor)

\section{Note}

1 R Reiner, Crime: the mystery of the common-sense concept, Cambridge: Polity, 2016, Kindle location 2427.

2 C Stone, Crime, justice, and growth in South Africa: toward a plausible contribution from criminal justice to economic growth, Center for International Development, Working Paper, 131, 2006, http://www.treasury.gov.za/publications/other/growth/07-Crime/01-

CRIME,\%20JUSTICE\%2OAND\%20GROWTH\%2OIN\%20SOUTH\%20AFRICA\%20-\%20TOWARDS\%2OA\%2OPLA.pdf (accessed 10 March 2017). 